\title{
Teacher conceptions of blended learning, blended teaching and associations with approaches to design
}

\author{
Robert A. Ellis \\ University of Sydney \\ Aliya F. Steed \\ The Australian National University \\ Andrelyn C. Applebee \\ University of Sydney
}

\begin{abstract}
This paper describes the results and implications of a qualitative study into teacher conceptions of blended learning, blended teaching and associations of these conceptions with approaches to design for blended learning experiences. Twenty-two teachers from two campus based Australian universities were interviewed and the responses from them were categorised into qualitatively varied categories of conceptions and approaches. The distribution of the categorisation is considered in relation to the strength of associations amongst the categories. In doing so, this study builds on previous research into understanding what teachers think students learn, how teachers think they teach, and how these understandings are related in blended contexts to the ways teachers prepare student learning through design. The results show that teacher conceptions of blended learning that focus on the use of technological media as one way of achieving learning outcomes and supporting critical investigation by students tend to be associated with conceptions of blended teaching which focus on helping students to develop new ideas and understanding.
\end{abstract}

\section{Introduction}

Higher education has embraced e-learning as a fundamental way of helping university students to learn. Evidence of a widespread international uptake of e-learning in students' university experience can be found on the websites of most universities, as well as in reputable research into university learning in journals and conferences. Towards the end of the last decade, some campus based universities may have perceived little 
advantage in systematic investment in e-learning, particularly technologies that facilitated flexible or distant learning. However, especially over the last five years, expectations from students and employers, a will to improve the professionalism of approaches to teaching and learning, and a desire to make the most of affordances from e-learning have combined to ensure that even campus based universities are either rolling out, or increasing their roll out of, e-learning technologies, video conferencing and audiovisual technologies. No matter the technology, the implicit goal of their use is to facilitate quality learning.

One of the main outcomes of the increased uptake of e-learning, particularly in predominately campus based universities, is the creation of student learning experiences that flow back and forth between face to face and online (or at least technologically supported) situations. The combination of face to face and online learning situations has created some concerns about how to best conceptualise and refer to such phenomena (Oliver \& Trigwell, 2005). Notwithstanding the pedagogical heterogeneity and conceptual fuzziness of the terms e-learning and blended learning, the former is used in this study to refer to web based learning and the latter is used to refer to systematic combinations of e-learning and face to face learning.

The effect of rolling out e-learning in campus based universities is, at best, an integration of technologies to meaningfully support face to face learning in a course, or, at worst, an addition to a course with little or no reflection of how the addition becomes part of the whole. There are many reasons why new technologies may not be fully integrated into the design of a course: the teacher may have little time, resources, knowledge or inclination to attend to the integration sufficiently, the infrastructure of the university may not be ready to support the technologies needed, or the culture of the discipline, either in disciplinary practice or in pedagogy, may not yet embrace the affordances of technology. Emergent knowledge preceding a resolution of many of these problems is a better understanding of how students learn in courses that depend on face to face and online contexts, how teachers teach successfully in such contexts, and how approaches to design for such contexts are related to approaches to teaching.

Beginning with an awareness that teachers in campus based universities are introducing e-learning into courses which previously were predominately face to face, this study is designed to investigate what teachers think students learn in courses that combine face to face and elearning experiences, how teachers think about their teaching in such contexts, and how teacher approaches to the design of blended experiences are related to their conceptions of teaching. In doing so, this study begins 
to address some of the potential misconceptions surrounding ideas of quality blended learning, and teaching experiences and approaches to the design of courses for blended contexts.

\section{Prior research}

Conceptions of learning and teaching have been the focus of sustained and influential research over the last three decades (Säljö, 1979; Marton, Dall'Alba \& Beaty, 1993; Prosser, Trigwell \& Taylor, 1994; Prosser \& Trigwell, 1999; Ramsden 2002). One of the first studies identified variation in how adult students conceived of learning (Säljö,1979). That study identified five qualitatively different conceptions; 'increasing knowledge', 'memorisation', 'acquiring facts and procedures', 'abstracting meaning' and 'understanding reality'. Marton and colleagues followed up on this about a decade later with a study that added to Säljö's findings with a sixth conception of learning that identified learning as 'changing as a person' (Marton, Dall'Alba \& Beaty, 1993). The significance of this type of work is that it allows the quality of learning experiences to be evaluated in terms of how different conceptions of learning are associated with other key aspects of university learning, such as approaches to learning and levels of achievement. This knowledge can then be used by others seeking evidence upon which to base decisions surrounding the facilitation of quality experiences for student learning.

Prosser and Trigwell (1994) followed with some work which, for the first time, investigated teacher conceptions of student learning, as well as teacher conceptions of teaching. They identified five qualitatively different categories of teacher conceptions of student learning:

a. Learning as accumulating more information to satisfy external demands

b. Learning as acquiring concepts to satisfy external demands

c. Learning as acquiring concepts to satisfy internal demands

d. Learning as conceptual development to satisfy internal demands

e. Learning as conceptual change to satisfy internal demands

There is a qualitative shift between categories b. and c., in which the demands of learning shift from the external (for example, the teacher), to the internal (the student).

In the same study, six conceptions of teaching were identified:

a. Teaching as transmitting concepts of the syllabus

b. Teaching as transmitting the teachers' knowledge

c. Teaching as helping students acquire concepts of the syllabus

e. Teaching as helping students acquire teacher knowledge 
f. Teaching as helping students develop conceptions

g. Teaching as helping students change conceptions.

The most significant qualitative shift in the above categories occurs between categories $\mathrm{d}$. and e., in which the perspective of the category moves from the teacher to the student.

While the same type of methodology is yet to be applied to teacher conceptions of blended learning, there has been some related research which has investigated academics' educational beliefs and associations with design, use and practice (Bain et. al., 1998a; 1998b; 2000). One of the main outcomes of this research is the identification of dimensions which help with the classification of computer facilitated learning environments in terms of their associations with the beliefs of academics. Bain and colleagues draw on, and extend, the dimensions proposed by Reeves (1992) which analyse computer facilitated learning in terms of its underlying pedagogical dimensions. They provide a perspective on the key dimensions of computer facilitated learning, which include: the learning framework, referring to the extent of scaffolding or structuring provided by the teaching and learning environment; the origin of the knowledge, referring to the source of the knowledge base (student, collaborative, discipline); the learning directions, referring to the extent of control students have over the environment; the knowledge focus, referring to the focus of the reasoning in the teaching and learning environment (eg conceptual/procedural reasoning, conceptual/procedural knowledge, case based reasoning); and the learning process, referring to the design and implementation. One of the main features of this work is that it attempts to analyse the dimensions of e-learning environments in terms of what academics actually think and do.

This study adds to and extends the previous research by investigating the conceptions of blended learning and teaching by teachers in two predominately campus based Australian universities, and associations amongst these conceptions to their approaches to design. In doing so, it aims to improve our understanding of the terms blended learning and teaching, and their relationship to approaches to design.

\section{Method}

\section{Research participants}

Teachers participating in this study came from two research intensive, campus based, metropolitan Australian universities. Twenty-two teachers agreed to take part, eleven from the first university and eleven from the second university. All had introduced web based learning into their course designs which had previously been predominately face to face. 
Table 1: Profiles of courses taught by the interviewees from the first university

\begin{tabular}{|c|c|c|c|c|c|}
\hline \multirow[b]{2}{*}{ Level } & \multirow[b]{2}{*}{ Discipline } & \multirow{2}{*}{$\begin{array}{l}\text { Course } \\
\text { size }\end{array}$} & \multicolumn{3}{|c|}{ Type of technologies and resources used } \\
\hline & & & $\mathrm{LMS}^{*}$ & $\begin{array}{l}\text { Interactive } \\
\text { resources }\end{array}$ & $\begin{array}{l}\text { Informational } \\
\text { resources }\end{array}$ \\
\hline $\begin{array}{l}\text { Later } \\
\text { year, UG }\end{array}$ & Japanese & $<60$ & WebCT & $\begin{array}{l}\text { Language } \\
\text { laboratory, audio } \\
\text { files }\end{array}$ & $\begin{array}{l}\text { Lectures and } \\
\text { digital sound } \\
\text { files }\end{array}$ \\
\hline $\begin{array}{l}\text { Later } \\
\text { year, UG }\end{array}$ & Engineering & 300 & - & Textbook website & $\mathrm{CD}$ \\
\hline $\begin{array}{l}\text { First year, } \\
\text { UG }\end{array}$ & $\begin{array}{l}\text { Information } \\
\text { Systems }\end{array}$ & 250 & $\begin{array}{l}\text { Other (own } \\
\text { web site on } \\
\text { faculty server) }\end{array}$ & $\begin{array}{l}\text { Discussion board } \\
\text { using web log/blog }\end{array}$ & - \\
\hline $\begin{array}{l}\text { First year, } \\
\text { UG }\end{array}$ & French & $<60$ & WebĆT & $\begin{array}{l}\text { Case studies and } \\
\text { language labs }\end{array}$ & $\begin{array}{l}\text { Original } \\
\text { video and } \\
\text { audio CD }\end{array}$ \\
\hline $\begin{array}{l}\text { Later } \\
\text { year, UG }\end{array}$ & \begin{tabular}{|l} 
Legal \\
History
\end{tabular} & $<60$ & WebCT & $\begin{array}{l}\text { Case studies, } \\
\text { discussion board } \\
\text { and interactive } \\
\text { movie linked to web }\end{array}$ & - \\
\hline $\begin{array}{l}\text { Later } \\
\text { year, UG }\end{array}$ & Forestry & $<30$ & Bespoke & $\begin{array}{l}\text { Hypertext pages } \\
\text { linked to discussion } \\
\text { tool }\end{array}$ & $\begin{array}{l}\text { Digital } \\
\text { lectures }\end{array}$ \\
\hline $\begin{array}{l}\text { Postgrad- } \\
\text { uate }\end{array}$ & $\begin{array}{l}\text { Legal } \\
\text { Practice }\end{array}$ & 400 & WebCT & $\begin{array}{l}\text { Support sheets for } \\
\text { exercise and } \\
\text { reflection }\end{array}$ & $\begin{array}{l}\mathrm{CD} \text { and } \\
\text { videos }\end{array}$ \\
\hline $\begin{array}{l}\text { First year, } \\
\text { UG }\end{array}$ & German & $<60$ & WebCT & $\begin{array}{l}\text { Chat rooms in } 2 \\
\text { languages, audio } \\
\text { and video } \\
\text { interactive CDs, } \\
\text { student web pages, } \\
\text { language lab }\end{array}$ & - \\
\hline $\begin{array}{l}\text { First year, } \\
\text { UG }\end{array}$ & Business & 600 & WebCT & Textbook website & $\begin{array}{l}\text { Commercial } \\
\text { case studies }\end{array}$ \\
\hline $\begin{array}{l}\text { First year, } \\
\text { UG }\end{array}$ & $\begin{array}{l}\text { Mathem- } \\
\text { atics }\end{array}$ & 150 & WebCT & $\begin{array}{l}\text { Bespoke applets and } \\
\text { MPEG files. Quizzes }\end{array}$ & - \\
\hline $\begin{array}{l}\text { Postgrad- } \\
\text { uate }\end{array}$ & Finance & $<60$ & WebCT & $\begin{array}{l}\text { Email used as } \\
\text { discussion tool }\end{array}$ & $\begin{array}{l}\text { References } \\
\text { available }\end{array}$ \\
\hline
\end{tabular}

The first university

The participants from the first university came from a range of disciplinary backgrounds including; languages (3), business and finance (3), law (2), science (2) and engineering (1). All were involved with teaching at either the undergraduate (UG) or postgraduate (PG) level. Five participants taught courses at first year level, four at second or third year level, and two in postgraduate diploma or masters degree programs. Class sizes in this group ranged from less than 20 to over 600 students. Six taught courses with less than 60 enrolled students, which is largely reflective of the 
university's relatively small undergraduate and postgraduate coursework population. The five larger courses each had between 150 and 600 enrolled students. Each course had a range of face to face contact hours per week (15) with the exception of the two-week intensive Legal Practice workshop. Face to face contact included a variety of lectures, laboratories, tutorials, workshops, seminars and field trips. Table 1 identifies key aspects of variation in the course profiles.

The technologies used by interviewees in the first university depict those common to many universities at this time. The most common technology is the development of a course website using a learning management system (LMS) provided by the university. Those with some expertise in technologies created software programs and learning tools that were designed specifically for the learning context. These can be referred to as 'made to measure' or 'bespoke' technologies.

The learning resources can be categorised under two headings, interactive (with the aim of encouraging students to develop their own perspectives as self paced, independent learners, often in enquiry based or experiential learning modes) and informational (with the aim of providing supplementary resources for students to access). Examples of interactive resources included case studies (with associated worksheets, quizzes and assessment); synchronous discussion tools (chat room); asynchronous discussion tools (email, discussion board, web blogs, student home pages); access to commercial sites (text books and work sheets); use of audio files in language laboratories and the creation of java applets and MPEG files. In the second category of informational resources, here the interviewees prepared lecture notes in various formats (Word, PDF, PowerPoint, audio files), and provided access to stand alone DVDs, CDs and videos and to reference material.

The second university

There were eleven participants from the second university, the majority teaching in the sciences (8), some teaching business and marketing (2), and one teaching engineering. Three participants were currently teaching courses at first year undergraduate level, six at second or third year undergraduate level and two in postgraduate diploma or degree programs. Class sizes ranged from 20 through to over 300 students. Of the eleven interviewees three taught courses with less than 60 enrolled students and eight taught larger courses with between 100 and 300 enrolled students. Each course had a range of face to face contact hours per week (2-5), comprising a variety of lectures, tutorials, laboratory sessions, seminars, demonstrations, excursions, clinics and sometimes even intensive weekend practical blocks. Table 2 identifies key aspects of variation in the course profiles. 
Table 2: Profiles of courses taught by the interviewees from the second university

\begin{tabular}{|c|c|c|c|c|c|}
\hline \multirow{2}{*}{ Level } & \multirow{2}{*}{ Discipline } & \multirow{2}{*}{$\begin{array}{l}\text { Course } \\
\text { size }\end{array}$} & \multicolumn{3}{|c|}{ Type of technologies and resources used } \\
\hline & & & LMS & $\begin{array}{c}\text { Interactive } \\
\text { resources }\end{array}$ & $\begin{array}{l}\text { Informational } \\
\text { resources }\end{array}$ \\
\hline $\begin{array}{l}\text { First year } \\
\text { UG }\end{array}$ & Vet Science & 120 & WebCT & $\begin{array}{l}\text { Email used as a } \\
\text { discussion tool }\end{array}$ & $\begin{array}{l}\text { Video and } \\
\text { annotated still } \\
\text { pictures. Lecture } \\
\text { notes }\end{array}$ \\
\hline $\begin{array}{l}\text { First year } \\
\text { UG }\end{array}$ & Vet Science & 120 & WebCT & $\begin{array}{l}\text { Quizzes, } \\
\text { assignment } \\
\text { submission. }\end{array}$ & $\begin{array}{l}\text { Lecture notes, } \\
\text { handouts and } \\
\text { image bank }\end{array}$ \\
\hline $\begin{array}{l}\text { First year } \\
\text { UG }\end{array}$ & Vet Science & 120 & WebCT & $\begin{array}{l}\text { Case studies on CD } \\
\text { and assignment } \\
\text { submission. }\end{array}$ & $\begin{array}{l}\text { Video and audio } \\
\text { files. Lecture } \\
\text { Notes }\end{array}$ \\
\hline $\begin{array}{l}\text { Combined } \\
\text { UG and } \\
\text { PG }\end{array}$ & Agriculture & 20 & - & $\begin{array}{l}\text { Case studies on } \\
\text { CD, email, quizzes }\end{array}$ & $\begin{array}{l}\text { Notes and } \\
\text { practical } \\
\text { handouts }\end{array}$ \\
\hline $\begin{array}{l}\text { Third year } \\
\text { UG }\end{array}$ & Vet Science & 120 & WebCT & $\begin{array}{l}\text { Case studies on } \\
\text { web-CD hybrid, } \\
\text { quizzes with } \\
\text { solutions, } \\
\text { databases, email }\end{array}$ & $\begin{array}{l}\text { High grade past } \\
\text { essays in html, } \\
\text { image library }\end{array}$ \\
\hline $\begin{array}{l}\text { First year } \\
\text { UG }\end{array}$ & $\begin{array}{l}\text { Health } \\
\text { Science }\end{array}$ & 130 & WebCT & $\begin{array}{l}\text { Case study, } \\
\text { quizzes and } \\
\text { worksheets }\end{array}$ & Lecture notes \\
\hline $\begin{array}{l}\text { Second } \\
\text { year UG }\end{array}$ & \begin{tabular}{|l} 
Civil \\
Engineering
\end{tabular} & 138 & WebCT & $\begin{array}{l}\text { Discussion board, } \\
\text { email, assignments } \\
\text { with solutions }\end{array}$ & $\begin{array}{l}\text { Lecture } \\
\text { overviews, } \\
\text { references }\end{array}$ \\
\hline $\begin{array}{l}\text { Second } \\
\text { year UG }\end{array}$ & Orthoptics & 40 & WebCT & $\begin{array}{l}\text { Discussion board, } \\
\text { case study, quiz, } \\
\text { assignment } \\
\text { submission, chat }\end{array}$ & $\begin{array}{l}\text { Lecture notes, } \\
\text { calendar tool }\end{array}$ \\
\hline $\begin{array}{l}\text { First year } \\
\text { UG }\end{array}$ & Archaeology & 35 & WebCT & $\begin{array}{l}\text { Assignment } \\
\text { submission, } \\
\text { weekly interactive } \\
\text { planner, email }\end{array}$ & $\begin{array}{l}\text { Lecture notes, } \\
\text { references and } \\
\text { image database }\end{array}$ \\
\hline $\begin{array}{l}\text { Third year } \\
\text { UG }\end{array}$ & Accounting & 300 & BlackBoard & Discussion board & $\begin{array}{l}\text { Lecture notes, } \\
\text { tutorial and } \\
\text { workshop } \\
\text { materials. }\end{array}$ \\
\hline $\begin{array}{l}\text { PG and } \\
\text { UG }\end{array}$ & Marketing & 85 & BlackBoard & Discussion board & $\begin{array}{l}\text { Lecture notes, } \\
\text { reference } \\
\text { resources }\end{array}$ \\
\hline
\end{tabular}

The participants from the second university used a similar range of technologies to those used by participants from the first university. Again the most common technology was the course website, developed using a 
learning management system supplied by the university or faculty. These were supplemented with additional resources which can be broken into interactive (Laurillard, 2002) and informational categories. Interactive, problem based case studies (generated from real world examples) with self directed worksheets and assessable quizzes, and synchronous and asynchronous discussion tools for both public and private individuals and groups of students, were the most predominant interactive resources. Theses resources were used for formative and summative assignment and assessment items.

Informational resources were provided in the form of lecture notes and overviews in a variety of formats (Word, HTML, PDF, PowerPoint, audio files), reference resources, and where relevant, access to image databases, video or audio files to enhance the blended experiences of their students. Interviewees commented that they intended that the technology should enhance and facilitate interactions between their students to build learning communities and to help them construct new fields of knowledge.

Participants were interviewed individually for 45-60 minutes and, after establishing their general teaching parameters, three questions were asked that focused on their conceptions of blended teaching, blended learning and their approach to designing blended learning experiences. The questions were:

1. What do you mean by blended learning?

2. What do you mean by blended teaching?

3. How do you approach designing blended experiences of learning?

Probing follow up questions such as "What advice would you give to your students if you wanted them to adopt a good approach to blended learning?" were used to get a new perspective on the same issue. Any words used in participants' responses which could require further clarification, such as 'integrate', 'understand', 'interact' and 'apply' were questioned. Each interview was audiotaped, transcribed verbatim and then analysed phenomenographically by the three researchers. The phenomenographic process was similar to that used by Crawford et al, (1994) and Prosser, Trigwell and Taylor (1994) to create a hierarchy of qualitatively different categories of concepts and approaches with representative quotations.

Early analysis of six transcripts assisted in the development of initial ideas of the conceptions of blended learning and blended teaching (in particular, whether interviewee's conceptions were cohesive or fragmented; or student or teacher centred) and approaches to design blended learning, in particular, whether the interviewees were aware of the developmental 
processes underpinning the design stage. These terms are discussed in the results.

After reading all transcripts a draft set of categories was devised and further refined after discussion and debate by the researchers, until a comprehensive set of categories of conceptions was abstracted from the responses. To support the categorisation of the four levels (A to D) of descriptions for each question (see the Results section below), representative extracts from the transcripts were chosen and discussed and debated by the researchers. Not all transcripts were easy to categorise and some created significant discussion amongst the researchers. The final distribution shown in Table 6 was agreed to by all researchers.

In the discussion of the results that follows, some clarification of the terms is required. There is some distinction to be made between learning outcomes and intended learning outcomes (Biggs, 2005), the former being realised learning outcomes measured through some type of assessment or evaluation, and the latter being the a priori student outcomes designed by the teacher. In terms of the various technologies used, they are conceived as part of the broader term of educational media after Laurillard (2002). Educational media includes non-technological media (lectures, seminars, tutorials, laboratories, print) as well as technological media (video, asynchronous and synchronous discussions, databases, CDs, etc).

\section{Results}

The following categories of description of blended learning, blended teaching and approaches to design for blended contexts are the main outcome of the analyses. Each group of categories begins with a classification letter from $\mathrm{A}$ to $\mathrm{D}$, followed by a descriptive phrase for the category, a paragraph that describes the key aspects of the category, and quotations that best represent the meaning of the category.

\section{Blended learning (a perspective of teachers on student learning)}

These results summarise and analyse teacher responses to the question 'What is blended learning?" Four categories of conceptions of blended learning were identified from responses in the interviews. These are labeled from category A, which is the most cohesive conception of blended learning and in which a student perspective is prominent, to category D, which is the most fragmented conception of blended teaching, in which a technological perspective is dominant. 


\section{Category A: Blended learning as critically investigating changes in the world around us}

This category reflects a cohesive conception of blended learning, meaning that there is a sense of purpose, connectedness and dependency between the use of technological media and student learning. It reveals a prominent awareness of a student perspective that is closely associated with meaningful learning. Application of learning experiences to real world situations are exemplified, often at unexpected places or times. Relating learning to the daily lives of students and future professional aspirations is a feature of this category of conception. An awareness of a changing experience of learning supported by technologies is emphasised.

I don't want them to just sort of, enter the class room and go 'ok, now I'm doing Information Systems 101'. I want them to think about this when they leave the classroom and they're out on a Saturday night and they see someone trying to work their mobile phone when they're drunk ... because that is Information Systems 101 right, happening right there. Why can't the person use it when they're drunk? Should they be able to? This kind of thing and I've got a few students who will email me at the drop of a hat to say, 'something interesting just happened in our office, have a listen to this'. So it is getting through to some students. (6)

The role of the teachers is just as important as it ever was except it's changing in the same way as the learning is. The practices, habits, the way of looking at things, maybe you can think in terms of skills, new skills for a new generation... you can have the best course but if the students cannot get something out of it in the way of acquiring skills that they can transfer, makes them construct their learning practice, then I don't think it will be a progress. (4)

They understood the etiology of the refractive errors and the management and were able to apply it to a particular situation and how a person is influenced by their refractive error in their daily lives and it was quite closely related to what my overall goals were for the course.(20)

\section{Category B: Blended learning as actively building understanding}

Responses in this category also indicate cohesive understanding of blended learning. While it is not quite as broad as the previous conception as it does not look beyond the boundaries of the course, but it does retain a strong student perspective. It emphasises an active aspect of learning: learning by doing, by engaging in a stimulating mix of activities over which students have control, by developing excitement and interest in doing it themselves. It is a conception of learning which is orientated towards notions of investigation and enquiry. 
I expect, well I am hoping the good students will find this a stimulating mix of their activity that they have some control over at least for the times when they are not in class with an instructor... Although they have control over that too because we get lots of, interaction and lots of discussion and that I suppose is an ideal from our point of view that the classes aren't us talking at people, but a dialogue with students and so that when they get to class they are already ready to be strong participants rather than you know being traditional under graduate sponges. So I suppose I have got this sense from a student point of view it should be an active rather than passive type of experience that they are having.(2)

My idea is to get them excited and interested and doing stuff for themselves or move towards a research orientation than just information.(21)

I suppose I like to use the term scaffolding, they can take their case notes and they can develop much deeper theses around their topic in relation to the final assessment.(9)

\section{Category C: Blended learning as replicating ways of learning using different media}

Responses in this category can be described as fragmented, meaning that they suggest a conception of blended learning that separates the use of technological media from student learning. There is no sense of a purposeful relationship between the technologies used and the facilitation or support of meaningful learning. There is a tendency in this category to emphasise the role of technological media at the expense of losing the perspective of the student on the experience. A teacher centred perspective is commonly adopted within this type of conception. It focuses on using the technological part of a blended experience to deliver a volume of information through different media, assuming that the same information accessed via different media will induce learning.

I think it's providing the material in a variety of different ways that address the different sort of needs of the students ... people learn in different ways. Some people learn visually, some people learn by reading. And for the teacher, I think that successful blended learning is good for them because it provides the teacher with variety. You know, it's terribly boring to give. You know, three lectures a week for the whole semester and that's all you do. It gets very tedious, where if you can think of creative ways of presenting the material and interacting with the students it's much more exciting for you as a teacher, I think. (14)

I try to cover the material but it gives me the flexibility to bring in heaps of other extraneous stuff. (16)

I wanted the students to sit and actively participate in taking in the information.(15) 
Category D: Blended learning as using all the different media

This is also a fragmented conception of learning. It is fragmented in the sense that there appears to be no relationship between the technological media and student learning. There is little awareness of student learning as a process facilitated by teaching, let alone the role of the technology in this process. Students interacting with the media at all is considered the same as meaningful learning.

There is an even greater emphasis on the media themselves, in comparison to category $C$, and this time the media are seen almost as mechanisms of learning. There is almost some sort of agency role attributed to the use of different media in learning, as if the media will impart learning onto students. A teacher centred perspective on learning is typical.

Let me say, how the students in my two courses in the semester are learning, they are attending presentation lectures and tutorials and they're doing assignments in the normal old fashioned way, lets call it. But they're also learning through the early issue of handouts.(19)

Blended learning means using all the materials rather than only the text book and the hard copy work book which is something that they purchase. (3)

Print all your lecture notes and print them out, put clamps through it, bring it to the class you know they would have four on one page, they do not waste the paper, and start writing when I am talking and they are listening to me and they use these guides as things to write down.(5)

Table 3 summarises key referential and structural aspects of the categories of conceptions of blended learning held by the teachers interviewed.

Table 3: Conceptions of blended learning

\begin{tabular}{|c|c|c|}
\hline \multirow[b]{2}{*}{ Referential } & \multicolumn{2}{|c|}{ Structural } \\
\hline & $\begin{array}{c}\text { Cohesive - a student } \\
\text { perspective }\end{array}$ & $\begin{array}{c}\text { Fragmented - a } \\
\text { technological perspective }\end{array}$ \\
\hline Investigating real world changes & $\mathrm{A}$ & \\
\hline Actively building understanding & B & \\
\hline Media replicating learning & & C \\
\hline Using different media & & $\mathrm{D}$ \\
\hline
\end{tabular}

\section{Blended teaching (a perspective of teachers on teaching)}

These results summarise and analyse teacher responses to the question 'What is blended teaching?" Four categories of conceptions of blended teaching were identified from responses in the interviews. These are labeled from category A, which is the most cohesive conception of blended teaching and in which intended student learning outcomes (Biggs, 2005) 
are prominent, to category $\mathrm{D}$, which is the most fragmented conception of blended teaching, in which a teacher perspective is dominant.

Category A: Blended teaching as helping students develop and apply new concepts

Category A is the most holistic conception of blended teaching. At the heart of this understanding of blended teaching is an awareness of intended student learning outcomes as enabled by the technologies. There is some variation in the way teachers expressed this fundamental notion. Some emphasise a role of teaching that foregrounds the importance of developing student thinking, of supporting student processes of thought and reflection, rather than delivering decontextualised content. An emphasis on the importance of helping students to be able to apply basic concepts of their discipline to the real world is apparent. Also apparent is the importance of helping students to develop an evidence based approach to analysing issues that will confront them in their future professions.

Mediating them into thinking. That's what you are here for you are not there to pass on content. You are there to enhance their thinking process and give them the means to access the different things, while thinking not thinking of easy solutions to finish the essays. (4)

One of the simplest concepts we try to get across is that when you're trying to measure the natural environment, you never actually measure the real object, you measure a simplification of it ...they're given various levels of resources, you know, they're given a piece of string and with that piece of string they have to work out what the area is so unless they know the theory, that they've actually converted from a model they can measure up the model and apply it to the real world, they're stuffed. (8)

My hope would be that they... that they've got the tools to tackle a behaviour modification program and as far as animal welfare science is concerned, they've got a scientific framework to use when approaching ethical dilemmas, or welfare issues, just not falling into the traps of making emotive arguments that can't be substantiated. (17)

It is interesting to note in this conception, that the role of technology is almost invisible. When probed in the interviews, it appeared that it was taken for granted by the interviewees that the role of technology is to promote thinking and application of learning.

Category B: Blended teaching as developing student understanding through aligning media to intended learning outcomes

Category B is also a cohesive conception of blended teaching: one that is aware of a close alignment between the purpose of the technology used and the intended student learning outcomes sought. Unlike category A, 
there is a more explicit discussion of a need to orientate the technology used in blended contexts to learning outcomes. Like category A, however, there is an awareness that student learning outcomes are the orientating point of a blended experience of learning. Discussions were emphasised in this conception of blended learning, both face to face and online. They were seen as a way of relating content areas to applied learning processes, captured in text on discussion boards for reflective and evaluative purposes. Adopting a student perspective on how students might use the technologies and how this might relate to learning and assessment issues was emphasised, as was using CD or online materials to facilitate students' engagement in meaningful preparation for face to face sessions.

\footnotetext{
I think blended teaching to me would mean using a combination of multiple modes but this has to be aligned with student's learning outcomes so in terms of it's fine for me I am going to use lectures, I am going to use technology, I am going to use guests speakers and whatnot, but it has to be blended and aligned with students learning outcomes, so that students see that this blend somehow makes sense and it will be useful to them in terms of their learning outcomes. I don't think one can talk about blended teaching without talking about blended learning at the same time. (11)
}

Well there were a few different things that we did. The main one is discussions, online discussions where the students discussed...the discussion groups were used for students to discuss clinical cases related to the content area of the unit of study so different refractive cases where they had to apply the learning they'd done in lectures with the tutorials with the clinical and come to, umm, basically work out what the issues were with the particular cases and come up with a group answer. (20)

\section{Category C: Blended teaching as providing students with information}

Category $\mathrm{C}$ is a fragmented conception of blended teaching: one that separates a relationship between the intended learning outcomes of the course and the students' experience of the blended context. The role of the teacher was emphasised in this category. Blended teaching was conceptualised as something that provided variety, particularly by providing different ways of accessing information. In contrast to categories $A$ and $B$, there was little discussion of attempts to integrate knowledge across different media and/or align media and strategies with specific learning outcomes. While there was some awareness that different technological media offered opportunities for students to talk about their experiences, meaningful learning was considered serendipitous rather than an intended outcome. Such opportunities were more focused on stimulating interest or enjoyment, rather than purposefully targetting specific topics. This conception also tended to emphasise a use of the technological part of the experience for the purposes of transmitting information, such as putting up lecture notes. 
What I do is firstly put up all my course notes up on the web because I don't put up any of the images because I feel that we have a lot of different languages, different lot of names, difficult concepts and so if I provide all that information I know that the students have a solid grounding of information which is far better quality than the note taking, there is a high degree of absenteeism these days because students are working, off doing other things, and while putting lecture notes up creates a further absentee problem, at least you know that the students have access to good material instead of copying it from friends.(21)

By blended teaching, I mean providing the teaching in a number of modes. Now some of the modes, by blended teaching I mean, a mode might be a lecture and a different mode might be a workshop, which is quite aside from any online mode. So just face to face mode with the teacher and the class presenting just a lecture...then the online resources as a teacher, if you will, because the material is placed there by the teacher, myself, with the intent that the students interact with it, so it's another way of providing information, I mean, at least that's the way I see it.(14)

Because it (technology) would create much more variety, would give a variety of input, it would provide a variety of the activities because a lot of to make a class good is to have a lot of variety, to have speed. This is much easier if you can blend, it widens enormously.(3)

\section{Category D: Blended teaching as replacing part of the responsibility of being a teacher}

Category D is also a fragmented conception of blended teaching: one that emphasises the technology at the expense of any meaningful relationship to either the face to face context or the learning outcomes of students. Blended teaching was conceptualised as a way of abstaining from part of the learning and teaching experience: getting students to complete learning activities without being in the room; filling little gaps in their learning experience when they are not in class. It is almost as if online materials become the voice of the teacher, which is seen as the main function of the materials. Comments placed within this category came from staff whose transcripts revealed no awareness of the benefits and synergies arising from technologies, extending, elaborating, enhancing the learning experience. Rather they tended to be a deficit type conception of their use.

It (blended teaching) means getting them to do some sort of valuable learning activities without me being there in the room with them. That is a key aspect of it. (2)

I love the introduction of notes and having them available through the (online) teaching...looking at it, getting a video clip, obviously they're going to learn. (15) 
Table 4 summarises the key referential and structural aspects of the categories of conceptions of blended teaching held by the teachers interviewed.

Table 4: Conceptions of blended teaching

\begin{tabular}{|l|c|c|}
\hline \multirow{2}{*}{ Referential } & \multicolumn{2}{|c|}{ Structural } \\
\cline { 2 - 3 } & $\begin{array}{c}\text { Cohesive - supporting } \\
\text { student learning }\end{array}$ & $\begin{array}{c}\text { Fragmented - } \\
\text { providing } \\
\text { technological media }\end{array}$ \\
\hline $\begin{array}{l}\text { Helping students develop and apply } \\
\text { new concepts }\end{array}$ & A & \\
\hline $\begin{array}{l}\text { Developing student understanding } \\
\text { through alignment of media to } \\
\text { learning outcomes }\end{array}$ & B & C \\
\hline $\begin{array}{l}\text { Using technological media to deliver } \\
\text { information }\end{array}$ & & D \\
\hline $\begin{array}{l}\text { Using technological media to replace } \\
\text { the teacher }\end{array}$ & & \multicolumn{2}{|c|}{} \\
\hline
\end{tabular}

\section{Approaches to design for blended learning experiences}

These results summarise and analyse teacher responses to the question "How do you approach designing blended experiences of learning?" Four categories of approaches to design were identified from responses in the interviews. These are labeled from category A, which is a deep approach to design and in which the design process reshapes approaches to teaching; to category $\mathrm{D}$, which is a surface approach to design, in which design seemed to be completely unrelated to approaches to teaching.

\section{Category A: Design reshapes approaches to teaching}

This category indicates a deep approach to design. The intent underpinning the design is to improve student thinking. This is accompanied by an awareness that the introduction of technological media into the design of the student experience usually warrants adjustments to the approaches adopted towards teaching.

It coincided with a big change in my pedagogy from pretty much straight lecturing to in other courses and embracing a lot more self direct in my learning as soon as my learning came on I mean we were doing this before my learning initiatives I thought we can do this stuff really works, I could see it in the small group in components of large classes...Small amounts of money actually producing profound revelations and revolutions in teaching and learning.(10)

When I first started teaching I thought that the undergraduates were thinking everything was too linear. You learnt this thing, you got it, you crossed it off and you do the next thing and you cross that off and then the 
next thing... and it was what I first of all tried to do, and there is where I fell in love with the world wide web and the Internet, was to show them that wherever you entered into the quantitative field it eventually took you everywhere else, and I thought that was the nice visualisation of the web. That, you start off with this picture and it just takes you, you keep going. And that's I think what I really wanted to get across to people, is that, to an extent it's a web, to an extent it's a fractal. You learn this bit and then you learn something else, you find out it's the first thing you learnt but it's a different application or it's the same thing. So there was a nice, simple, underpinning message that just kept expanding out and I found that putting that in something like the web, to me, was the medium itself was telling you something about the message and I like that idea. (8)

\section{Category B: Design influences approaches to teaching}

This category also demonstrates a deep approach to design. Technological media is integrated and embedded into the design of courses. There is an awareness that some time is required to embed technological media properly into the design of a course, and that some expertise may be required from a specialist or additional training. An incremental approach to the introduction of technological media, accompanied by a willingness to trial and pilot activities around new media is part of the approach.

It happened with even all these videos of the village... why do I choose this, how is this going to be useful, will it interest them and can it be integrated in a coherent way? (4)

I mean I still think that with a lot of these things you use one thing and use it well and you don't try and do too much, and then you build on it as time goes on.(20)

I started really small, like I just really, really small, just using discussions because I wanted students to interact more so I didn't worry about putting content or pictures or quizzes or anything like that...I rang up the help desk and got lots of help and went to all the, I went to as many workshops as I could.(20)

I do read their messages and I do respond when I see something appropriate, like this is an interesting point by the way', 'Have you come across this website?' in that sort of manner rather than correcting and that sort of thing. I do read their messages and often I picked out some interesting pieces if there is a type of posting or something and bring it back to the face-to-face environment and say 'hey, somebody posted this interesting point saying blah blah blah' 'What do you think about that?' and then we discuss it as a whole.(11)

\section{Category C: Design overwhelms relationships to teaching}

This is a surface approach to design. Unfamiliarity with, or the effort involved in, introducing technological media into the design of the 
curriculum is sufficient to overwhelm an awareness of how approaches to teaching can be sensibly modified to help embed and make the most of the media.

I am using the learning management system but more as a teacher depository tool than as an actual learning process... one is we have this new language lab has come in this year that everything had to be digitalised and electronic. We made digital files of all the textbook files as I said all the examples, practice in the text book they have only got the questions in their actual text. Whereas the tape then has the answers recorded in as well. I have made files of all those and that's all up on the web to access and a lot of them have downloaded it themselves.(1)

\section{Category D: Design is unrelated to teaching}

This is also a surface approach to design. Comments classified in this category revealed no significant awareness of links between design and approaches to teaching. There was also little awareness of the time or effort involved in design processes which were likely to lead to an integrated course.

I haven't thought about it too much because as I said, many times, once last year I wanted to learn how to drive the WebCT bus and having learnt how to drive it then enhanced the passengers enjoyment of their drive in the bus. (19)

I don't think there is really a difference... I don't think it has really changed the way I teach. (5)

I am not aware of all the added advantages that are out there. (12)

Table 5 summarises the key referential and structural aspects of the categories of approaches to design adopted by the teachers interviewed.

Table 5: Approaches to design for blended learning experiences

\begin{tabular}{|l|c|c|}
\hline \multirow{2}{*}{\multicolumn{1}{|c|}{ Referential }} & \multicolumn{2}{c|}{ Structural } \\
\cline { 2 - 3 } & $\begin{array}{c}\text { Deep - } \\
\text { embedded }\end{array}$ & $\begin{array}{c}\text { Surface - } \\
\text { unintegrated }\end{array}$ \\
\hline Design reshapes approaches to teaching & A & \\
\hline Design influences approaches to teaching & B & C \\
\hline Design overwhelms relationships to teaching & & D \\
\hline Design is unrelated to teaching & & \\
\hline
\end{tabular}




\section{Associations amongst categories of conceptions and approaches}

To investigate if there were any associations amongst what teachers thought students were learning in blended experiences, what they thought blended teaching was and their approaches to design for blended experiences, quantitative analyses of the distribution of teacher responses in the interviews were undertaken.

Table 6: The distribution of variation in conceptions of, and approaches to design for, blended experiences

\begin{tabular}{|l|l|c|c|c|}
\hline \multicolumn{3}{|l|}{ Conceptions/approaches } & $\mathrm{N}$ & $\%$ of responses \\
\hline \multirow{2}{*}{$\begin{array}{l}\text { Conception of } \\
\text { blended } \\
\text { learning }\end{array}$} & Cohesive & $\mathrm{A}$ & 3 & $14 \%$ \\
\cline { 2 - 5 } & & $\mathrm{B}$ & 8 & $36 \%$ \\
\cline { 2 - 5 } & Fragmented & $\mathrm{C}$ & 6 & $27 \%$ \\
\cline { 2 - 5 } & $\mathrm{D}$ & 5 & $23 \%$ \\
\cline { 2 - 5 } & Total & $\mathrm{A}$ & 3 & $100 \%$ \\
\hline \multirow{2}{*}{$\begin{array}{l}\text { Conception of } \\
\text { blended } \\
\text { teaching }\end{array}$} & Cohesive & $\mathrm{B}$ & 7 & $14 \%$ \\
\cline { 2 - 5 } & Fragmented & $\mathrm{C}$ & 4 & $32 \%$ \\
\cline { 2 - 5 } & & $\mathrm{D}$ & 8 & $18 \%$ \\
\cline { 2 - 5 } & Total & $\mathrm{A}$ & 2 & $36 \%$ \\
\hline \multirow{2}{*}{$\begin{array}{l}\text { Approaches to } \\
\text { design }\end{array}$} & Deep & $\mathrm{B}$ & 9 & $100 \%$ \\
\cline { 2 - 5 } & Surface & $\mathrm{C}$ & 5 & $9 \%$ \\
\cline { 2 - 5 } & & $\mathrm{D}$ & 6 & $23 \%$ \\
\cline { 2 - 5 } & Total & & 22 & $27 \%$ \\
\hline
\end{tabular}

Table 6 shows the categorisation of the variation in the categories of blended conceptions of learning and teaching and approaches to design. Fifty percent of teacher responses to the question about blended learning were classified as cohesive, categories A and B, while $50 \%$ were classified as fragmented, categories $\mathrm{C}$ and $\mathrm{D}$. To the question about blended teaching, $46 \%$ of teacher responses were classified as cohesive, and $54 \%$ were classified as fragmented. To the question about approaches to design for blended experiences, 50\% were classified as deep and 50\% were classified as surface.

To assess whether or not the distribution of teacher responses to the interview questions was statistically significant, a phi coefficient was calculated and a Fisher exact procedure was used. The Fisher exact procedure of testing the statistical significance of the phi coefficient is preferably used when the population is small and one of the numbers in the $2 \times 2$ table is less than 5 . 
Table 7: Associations amongst conceptions of blended learning and teaching and approaches to design

\begin{tabular}{|c|c|c|c|c|}
\hline 7.1 Blended learning * & Blended learning & Blend & aching & Total \\
\hline Blended teaching & Dienued iearning & Cohesive & Fragmented & \\
\hline cross tabulation & Cohesive & 9 & 2 & 11 \\
\hline & Fragmented & 1 & 10 & 11 \\
\hline & Total & 10 & 12 & 22 \\
\hline & phi $=.7, \mathrm{p}<.01, \mathrm{n}=2$ & & & \\
\hline 7.2 Blended learning * & Blended learning & Approa & to design & Total \\
\hline Approaches to design & Dienued Ieantmg & Deep & Surface & \\
\hline cross tabulation & Cohesive & 10 & 1 & 11 \\
\hline & Fragmented & 1 & 10 & 11 \\
\hline & Total & 11 & 11 & 22 \\
\hline & $\mathrm{phi}=.8, \mathrm{p}<.001, \mathrm{n}=$ & & & \\
\hline 7.3 Blended teaching * & Blended teaching & Approa & to design & Total \\
\hline Approaches to design & 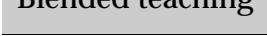 & Deep & Surface & 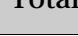 \\
\hline Cross tabulation & Cohesive & 8 & 2 & 10 \\
\hline & Fragmented & 3 & 9 & 12 \\
\hline & Total & 11 & 11 & 22 \\
\hline & phi $=.6, p<.05, n=2$ & & & \\
\hline
\end{tabular}

Table 7 part 7.1 shows a strong and statistically significant relationship between the conceptions of blended learning and teaching, (phi $=.7$, $\mathrm{p}<.01$ ). These results suggest that cohesive/ fragmented conceptions of blended learning are closely and logically associated with cohesive/ fragmented conceptions of blended teaching.

Table 7 part 7.2 shows a strong positive relationship between conceptions of blended learning and design ( $\mathrm{phi}=.8, \mathrm{p}<.001$ ). These results indicate that cohesive/ fragmented conceptions of learning are closely and logically associated with deep/ surface approaches towards design for blended experiences of learning.

Table 7 part 7.3 shows a strong positive relationship between conceptions of blended teaching and design (phi $=.6, \mathrm{p}<.05$ ). These results indicate that that cohesive/ fragmented conceptions of teaching are closely and logically associated with deep/ surface approaches towards design for blended experiences of learning.

\section{Limitations of this study}

While the outcomes of this study provide useful insights into the structure and meaning of blended experiences of learning and teaching at university, it is worth noting some limitations. The population sample comes from only two Australian universities and is relatively small $(n=22)$. Consequently, some of the categories are made up of only two or three 
responses. Some care should be taken with the interpretations of the categories give the limited number of responses. This qualification is also relevant for the associations identified in the quantitative analyses of the qualitative categorisation processes.

Having noted this, the population sample is similar to those used in previous research: Prosser, Trigwell and Taylor (1994), $\mathrm{n}=24$; Marton, Dall'Alba and Beaty (1993), $n=29$. To assess the robustness of the categories of this study, it should be followed with another that involves a larger population, preferably with participants from campus based universities in other countries.

\section{Discussion}

This study has investigated variation in the quality of conceptions of blended learning and teaching, and approaches to design for blended learning experiences, by university teachers. The teachers are from two research intensive, predominately campus based universities. As a sample, they use a range of proprietary and bespoke learning technologies to support learning experiences at undergraduate and postgraduate levels of university education. The results of the analyses of twenty two interview transcripts identified four qualitatively different categories of each of blended learning, blended teaching, and approaches to designing blended learning experiences.

Taking the outcomes of the analyses together, including the associations amongst conceptions of blended learning and teaching and approaches to design, this study has revealed significant relationships for understanding how blended learning and teaching can support quality student learning experiences.

The results show that conceptions of blended learning focusing on critical investigation of the environment that students find themselves in, and those that see technological media as one way of helping students to achieve the intended learning outcomes of course design, tend to be associated with helping students to develop new ideas and understanding. In contrast, conceptions of blended learning that emphasise technological media at the expense of student learning, tend to be associated with using media to deliver information or to even replace some responsibilities of being a teacher. Significantly, the former categories of blended learning and teaching are associated with approaches to design that influence the way teachers teach, and the latter categories of blended learning and teaching are associated with approaches to design which are not related to approaches to teaching. 
It is worthwhile noting that the outcomes are consistent with previous, closely related research. If we consider conceptions of learning and teaching (Prosser, Trigwell \& Taylor, 1994) and conceptions of blended learning and blended teaching in this study, there is broad consistency in the qualitative shifts between groups of categories of conceptions. In the earlier study, the lower quality conceptions were not student focused, while the higher quality conceptions were. Similarly in this study, the lower categories of conceptions do not focus on the student. Instead, there is an emphasis on a technological perspective. Categories C and D in this study not only ignore the student perspective, but tend to ignore associations amongst technological and non-technological media, emphasising the former at the expense of the latter. In contrast, the higher quality conceptions, $\mathrm{A}$ and $\mathrm{B}$, adopt a student perspective on learning and an awareness that the educational media can be aligned to support their intended learning outcomes.

It is useful to reflect on why technology overwhelmed many of the conceptions held by the teachers in this study. For most of the teachers interviewed, the technology was the most recent significant addition to the course design. It may be that the effort involved in embedding technology in course design, and the unfamiliarity surrounding some of the new technologies is such that it assumes a higher level of prominence in the awareness of some teachers. Perhaps familiarity with the technologies and incremental experimentation with how students use them will help some teachers to reconceive of how technological media are associated with blended learning and teaching. For others, however, it is likely that the introduction of technology exacerbates a conception of learning which is already teacher orientated. In both these cases, we need to better understand both the likely benefits and problems that are likely to occur when technology is introduced into the student experience of learning.

This study extends previous research by considering the associations of design to conceptions of blended learning and teaching. Design for learning (Goodyear, 2005; Laurillard, 2002) is a growing and important body of research as e-learning becomes embedded in student learning experiences in even predominately campus based experiences. Understanding relationships between approaches to design and learning and teaching is therefore increasingly important if we are to help teachers design experiences of learning that are likely to help students achieve intended learning outcomes. The outcomes from this study suggest that higher quality conceptions of blended and learning are associated to approaches to design that are embraced in the way teachers approach teaching the student experience of learning. Without an awareness that new design involving new technologies for student learning will require adaptations of teaching methodologies, neither the affordances of 
technologies, nor the benefits stemming from these for the quality of learning, are likely to be experienced by students.

While the outcomes of this study are significant, we are only at the beginning of understanding the complexity of relationships amongst student and teacher conceptions and approaches to blended experiences of learning in university, and how the quality of these experiences are related to course design. This is particularly true of predominately campus based learning experiences which have received comparatively less systematic research than distance learning contexts. We need much more evidence based research into how aspects of design are related to learning in ways that are likely to help students achieve the intended learning outcomes that their teachers spend their so much time in preparing.

\section{References}

Bain, J. D., McNaught, C., Mills, C. \& Lueckenhausen, G. (1998a). Describing computer-facilitated learning environments in higher education. Learning Environments Research, 1, 163-180.

Bain, J. D., McNaught, C., Mills, C. \& Lueckenhausen, G. (1998b). Understanding CFL practices in higher education in terms of academics' educational beliefs: Enhancing Reeves' analysis. In R. M. Corderoy (Ed), Flexibility: The next wave? Proceedings of the 15th ASCILITE Conference, Wollongong, Australia 14-16 December (pp. 49-58). Wollongong: University of Wollongong.

http://www.ascilite.org.au/conferences/wollongong98/asc98-pdf/bain0089.pdf

Bain, J. D., McNaught, C., Mills, C. \& Lueckenhausen, G. (2000). Relationship between academics' educational beliefs and their design and use of computer facilitated learning. In J. Bourdeau \& R. Heller (Eds), Proceedings of ED-MEDIA 2000: World Conference on Educational Media, Hypermedia \& Telecommunications, Montreal Canada, 26 June - 1 July, 2000 [CD]. Charlottesville, VA: Association for the Advancement of Computing in Education.

Biggs, J. B. (2005). Aligning teaching for constructing learning. Higher Education Academy Discussion Paper. [viewed 14 Jan 2006]

http:/ / www.heacademy.ac.uk/embedded_object.asp?id=21686\&filename=Biggs

Crawford, K., Gordon, S., Nicholas, J. \& Prosser, M. (1994). Conceptions of mathematics and how it is learned: The perspectives of students entering university. Learning and Instruction, 4, 331-345.

Goodyear, P. (2005). Educational design and networked learning: Patterns, pattern languages and design practice. Australasian Journal of Educational Technology, 21(1), 82-101. http://www.ascilite.org.au/ajet/ajet21/goodyear.html

Laurillard, D. (2002). Rethinking university teaching: A framework for the effective use of educational technology (2nd ed.). London: Routledge. 
Marton, F., Dall'Alba, G. \& Beaty, E. (1993). Conceptions of learning. International Journal of Educational Research, 19, 277-300.

Oliver, M. \& Trigwell, K. (2005). Can 'blended learning' be redeemed? E-Learning, 2(1), 17-26. [verified 5 Jul 2006]

http:/ / www.wwwords.co.uk/pdf/validate.asp?j=elea\&vol=2\&issue=1\&year=2005\&artic le=3_Oliver_ELEA_2_1_web

Prosser, M. \& Trigwell, K. (1999). Understanding learning $\mathcal{E}$ teaching: The experience in higher education. Buckingham: Society for Research into Higher Education \& Open University Press.

Prosser, M., Trigwell, K. \& Taylor, P. (1994). A phenomenographic study of academics' conceptions of science learning and teaching. Learning and Instruction, 4, 217-231.

Ramsden, P. (2002). Learning to teach in higher education. (2nd ed.) London: Routledge Falmer.

Reeves, T. C. (1992). Effective dimensions of interactive learning systems. Information Technology for Training and Education Conference (ITTE '92) (pp. 99-113). Brisbane, Australia: University of Queensland.

Säljö, R. (1979). Learning in the learner's perspective. I. Some common-sense conceptions. Reports from the Institute of Education, University of Gothenburg, 76.

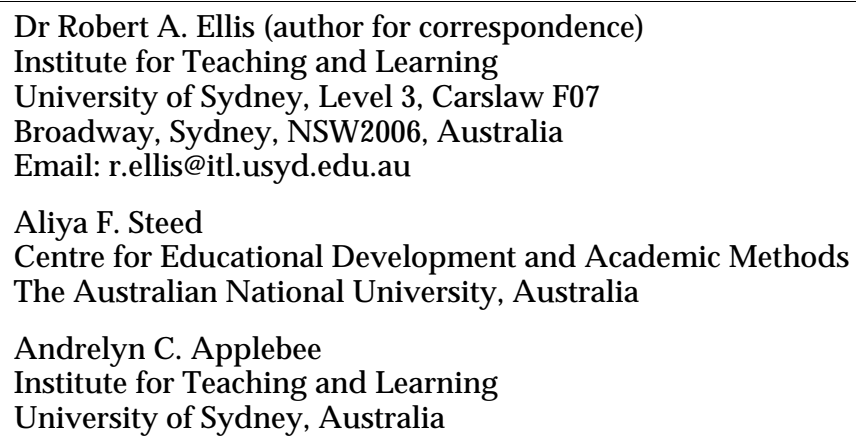

